\title{
PENINGKATAN MINAT BELAJAR PESERTA DIDIK MELALUI PENERAPAN MODEL PROJECT BASED LEARNING PADA PEMBELAJARAN PENDIDIKAN AGAMA ISLAM KELAS VIII.2 SMP NEGERI 2 SUPPA KABUPATEN PINRANG
}

\author{
Nur Anita ${ }^{1}$, St. Aminah Azis ${ }^{2}$, Buhaerah ${ }^{3}$ \\ IAIN Parepare \\ Email: Anitha_kasim@yahoo.com
}

\begin{abstract}
This study aims to improve student learning in Islamic Religious Education learning through the application of the Project Based Learning (PBL) class VIII.2 model of Junior High School 2 Suppa Pinrang Regency The variable that is the target of this research change is interest in learning. While the action variables used in this study are Project Based learning models. This type of research is classroom action research. The data collection techniques used are observation and documentation. In addition, the data analysis technique using descriptive statistics. The results showed an increase in students' learning interest from cycle I to cycle II had increased with an average score of 5,52. The improvement starts from the pre-cycle of 2,24 and then the Project Based Learning (PBL) model is implemented through the first cycle, increasing to 3,34 and continued in the second cycle, with a significand increase of 5,52. Thus, a recommendation can be submitted on the aplication of the Project Based Learning (PBL) model to increase students' learning interest in learning Islamic Education Class VIII.2 junior high school 2 Suppa Pinrang Regency 2018/2019 Academic Year.
\end{abstract}

Keywords: Project Based Learning Model, Learning Interest, Islamic Religious Education

\section{ABSTRAK}

Penelitian ini bertujuan untuk meningkatkan minat belajar peserta didik pada pembelajaran Pendidikan Agama Islam melalui penerapan model Project Based Learning kelas VIII.2 SMP Negeri 2 Suppa Kabupaten Pinrang. Variabel yang menjadi sasaran perubahan dalam penelitian ini 
adalah minat belajar. Sedangkan variabel tindakan yang digunakan dalam penelitian ini adalah model Project Based Learning. Jenis penelitian ini adalah penelitian tindakan kelas. Adapun tehnik pengumpulan data yang digunakan adalah observasi/pengamatan dan dokumentasi. Selain itu, tehnik analisis data yang digunakan adalah teknik analisis kuantitatif dengan menggunakan statistik deskriptif. Hasil penelitian menunjukkan terjadinya peningkatan minat belajar peserta didik dari siklus I ke siklus II mengalami peningkatan dengan rata-rata skor perolehan 5,52. Peningkatan ini berawal dari pra-siklus yaitu 2,24 kemudian diterapkan model Project Based Learning melalui siklus I, meningkat menjadi 3,34 dan dilanjutkan pada siklus II, dengan peningkatan yang signifikan yaitu 5,52. Dengan demikian, dapat diajukan suatu rekomendasi bahwa penerapan model Project Based Learning dapat meningkat minat belajar peserta didik pada pembelajaran Pendidikan Agama Islam kelas VIII.2 SMP Negeri 2 Suppa Kabupaten Pinrang Tahun Pelajaran 2018/2019.

Kata kunci : Model Project Based Learning, Minat Belajar, Pendidikan Agama Islam

\section{PENDAHULUAN}

Pendidikan adalah salah satu sistem yang sangat strategis dalam membekali manusia untuk menghadapi masa depannya, untuk mencapai kebahagiaan dunia dan akhirat sehingga pendidikan dan manusia saling berkaitan. Proses pendidikan terjadi perkembangan potensi diri sehingga mempunyai kemampuan untuk menghadapi kehidupan dimasa depan. Seperti diketahui, bahwa setiap pribadi mempunyai tingkat kemampuan yang berbeda dalam hal ini kurangnya minat belajar yang harus ditingkatkan dengan menggunakan model Project Based Learning (PBL).

Seiring dengan perkembangan zaman saat ini, pendidikan menjadi kebutuhan mutlak yang harus dipenuhi oleh setiap manusia sehingga dapat hidup berkembang, maju, sejahtera dan bahagia menghadapi masa depan yang penuh dengan cobaan. Pendidikan yang terjadi pada sekolah SMP Negeri 2 Suppa khususnya pada kelas VIII.2 bisa di katakan berjalan dengan baik, dikarenakan proses pembelajaran berlangsung sesuai yang diharapkan. 
Seorang guru bukan hanya dituntut memiliki kemampuan untuk menyampaikan pelajaran kepada anak didik dengan baik. Seorang guru juga harus mampu mengarahkan peserta didiknya agar mereka bisa mengetahui dengan baik dan jelas pelajaran yang telah disampaikan. Dengan demikian, tugas belajar benar-benar akan menjadi suatu petualangan dan menyenangkan yang dilakukan oleh guru dan diikuti oleh peserta didik, dan bukan menjadi ajang ceramah yang membosankan untuk didengar peserta didik.

Guru adalah pahlawan tanpa tanda jasa, tanpa pamrih dia bertanggung jawab mencerdaskan setiap peserta didiknya. Tidak ada seorang pendidik yang ingin membuat peserta didiknya menjadi sampah masyarakat. Begitu besar tanggung jawab seorang guru terhadap peserta didiknya biar hujan maupun panas, bukanlah penghalang baginya untuk selalu hadir di tengah-tengah peserta didiknya. Tetapi melihat realita sekarang ini banyak peserta didik yang kurang sopan dan tidak tahu cara menghormati gurunya. Nasehat yang di berikan pendidik terhadap peserta didiknya dengan ikhlas, tetapi dibalas dengan kekerasan.

Minat adalah suatu rasa lebih suka dan rasa keterikatan pada suatu hal atau aktivitas, tanpa ada yang menyuruh. Minat pada dasarnya adalah penerimaan akan suatu hubungan antara diri sendiri dengan sesuatu di luar diri. Semakin kuat atau dekat hubungan tersebut, semakin besar minat.

Model pembelajaran adalah suatu rencana atau pola yang digunakan untuk membentuk pembelajaran (rencana pembelajaran jangka panjang), merancang bahan-bahan pembelajaran, dan membimbing pembelajaran di kelas atau yang lain dan menjadi salah satu penunjang keberhasilan suatu pembelajaran. Pembelajaran berbasis proyek Project Based Learning (PBL) adalah model pembelajaran yang menggunakan proyek sebagai inti pembelajaran. Model pembelajaran ini merupakan model pembelajaran inovatif yang melibatkan kerja proyek dimana peserta didik bekerja secara mandiri dalam mengkonstruksi pembelajarannya dan mengkulminasikannya dalam produk nyata.

Model pembelajaran Project Based Learning (PBL) dikembangkan berdasarkan tingkat perkembangan berfikir peserta didik dengan berpusat pada aktivitas belajar peserta didik sehingga memungkinkan mereka untuk beraktivitas sesuai dengan keterampilan, kenyamanan, dan minat belajarnya. Model ini memberikan kesempatan pada peserta didik untuk menentukan sendiri proyek yang akan dikerjakannya baik dalam hal merumuskan pertanyaan yang akan dijawab, memilih topik yang akan diteliti, maupun 
menentukan kegiatan penelitian yang akan dilakukan. Peran guru dalam pembelajaran adalah sebagai fasilitator, menyediakan bahan dan pengalaman bekerja, mendorong peserta didik berdiskusi dan memecahkan masalah, dan memastikan peserta didik tetap bersemangat selama mereka melaksanakan proyek.

Model pembelajaran Project Based Learning (PBL) mempunyai beberapa karakteristik, yaitu sebagai berikut:

1. Mengembangkan pertanyaan atau masalah, yang berarti pembelajaran harus mengembangkan pengetahuan yang dimiliki oleh peserta didik.

2. Memiliki hubungan dengan dunia nyata, berarti bahwa pembelajaran yang outentik dan peserta didik dihadapkan dengan masalah yang ada pada dunia nyata.

3. Menekankan pada tanggung jawab peserta didik, merupakan proses peserta didik untuk mengakses informasi untuk menemukan solusi yang sedang dihadapi.

4. Penilaian, penilaian dilakukan selama proses pembelajaran berlangsung dan hasil proyek yang dikerjakan peserta didik.

Langkah-langkah Project Based Learning (PBL) sebagaimana yang dikembangkan oleh The George Lucas Educational Foundation terdiri dari:

1. Penentuan Pertanyaan Mendasar (Start With the Essential Question)

Pembelajaran dimulai dengan pertanyaan esensial yaitu pertanyaan yang dapat memberi penugasan kepada peserta didik dalam melakukan suatu aktivitas. Topik penugasan sesuai dengan dunia nyata yang relevan untuk peserta didik. Dan dimulai dengan sebuah investigasi mendalam.

2. Mendesain Perencanaan Proyek (Design a Plan for the Project)

Perencanaan dilakukan secara kolaboratif antara guru dan peserta didik. Dengan demikian peserta didik diharapkan akan merasa "memiliki" atas proyek tersebut. Perencanaan berisi tentang aturan main, pemilihan aktivitas yang dapat mendukung dalam menjawab pertanyaan esensial, dengan cara mengintegrasikan berbagai subjek

yang mungkin, serta mengetahui alat dan bahan yang dapat diakses untuk membantu penyelesaian proyek.

3. Menyusun Jadwal (Create a Schedule)

Guru dan peserta didik secara kolaboratif menyusun jadwal aktivitas dalam menyelesaikan proyek. Aktivitas pada tahap ini antara lain: membuat timeline (alokasi waktu) untuk menyelesaikan proyek, membuat deadline (batas waktu akhir) penyelesaian proyek, membawa peserta didik agar merencanakan cara yang baru, membimbing peserta didik ketika mereka 
membuat cara yang tidak berhubungan dengan proyek, dan meminta peserta didik untuk membuat penjelasan (alasan) tentang pemilihn suatu cara.

4. Memonitor peserta didik dan kemajuan proyek (Monitor the Students and the Progress of the Project)

Guru bertanggung jawab untuk melakukan monitor terhadap aktivitas peserta didik selama menyelesaikan proyek. Monitoring dilakukan dengan cara menfasilitasi peserta didik pada setiap proses. Dengan kata lain guru berperan menjadi mentor bagi aktivitas peserta didik. Agar mempermudah proses monitoring, dibuat sebuah rubrik yang dapat merekam keseluruhan aktivitas yang penting.

5. Menguji Hasil (Assess the Outcome)

Penilaian dilakukan untuk membantu guru dalam mengukur ketercapaian standar, berperan dalam mengevaluasi kemajuan masingmasing peserta didik, memberi umpan balik tentang tingkat pemahaman yang sudah dicapai peserta didik, membantu guru dalam menyusun strategi pembelajaran berikut.

6. Mengevaluasi Pengalaman (Evaluate the Experience)

Pada akhir pembelajaran, guru dan peserta didik melakukan refleksi terhadap aktivitas dan hasil proyek yang sudah dijalankan. Proses refleksi dilakukan baik secara individu.

Pembebelajaran Project Based Learning (PBL) merupakan model pembelajaran yang menggunakan proyek sebagai inti pembelajaran. Di dalam pembelajaran Project Based Learning (PBL) tentunya memiliki kelebihan dan kekurangan sebagai berikut:

1. Kelebihan Project Based Learning (PBL)

a. Meningkatkan motivasi belajar peserta didik

b. Meningkatkan keterampilan sosial dan berkomunikasi

c. Meningkatkan keterampilan dalam memecahkan permasalahan

d. Mendorong peserta didik untuk mampu mengkorelasikan antar disiplin ilmu

e. Mengembangkan kemampuan belajar peserta didik dengan berbagai pendekatan belajar

2. Kekurangan Project Based Learning (PBL)

a. Membutuhkan banyak waktu dalam menyelesaikan permasalahan

b. Membutuhkan banyak dana

c. Banyaknya peralatan yang mesti dipersiapkan

d. Peserta didik yang memiliki kelemahan dalam hal percobaan dan pengumpulan informasi akan mengalami kesulitan 
e. Akan adanya kemungkinan peserta didik yang tidak terlibat dalam kegiatan.

Keterkaitan antara minat belajar dengan penerapan model Project Based Learning (PBL) dapat terlihat dari kecenderungan peserta didik untuk memperhatikan pembelajaran dan menjawab suatu pertanyaan atau permasalahan yang di ajukan, munculnya kepuasaan karena rasa suka ketika sukses menyelesaikan masalah, peserta didik menyukai ketika diberi tugas untuk dipertanggungjawabkan terhadap permasalahan yang telah diselesaikan.

Berdasarkan hasil observasi sebelumnya pada kelas VIII.2 SMP Negeri 2 Suppa terkhusus pada pembelajaran Pendidikan Agama Islam terdapat sebagian besar peserta didik yang kurang minat dalam pembelajaran tersebut, hal ini dibuktikan dengan beberapa indikator di antaranya tidak senang mengikuti pelajaran Pendidikan Agama Islam, kemudiam tidak percaya diri dalam mengikuti pelajaran Pendidikan Agama Islam. Bertolak dari masalah tersebut maka, peneliti termotivasi untuk meneliti minat belajar Pendidikan Agama Islam peserta didik dengan menerapkan model pembelajaran Project Based Learning (PBL) tepatnya pada kelas VIII. 2 SMP Negeri 2 Suppa.

Dari uraian latar belakang masalah di atas, maka penulis dapat mengambil intisari untuk dijadikan sebagai masalah pokok dalam penulisan proposal yang berjudul "Peningkatan minat belajar peserta didik melalui penerapan model Project Based Learning (PBL) pada Pembelajaran Pendidikan Agama Islam kelas VIII.2 SMP Negeri 2 Suppa Kabupaten Pinrang".

Maka dapat dirumuskan pokok permasalahan penelitian sebagai berikut:

1. Bagaimana minat belajar peserta didik sebelum penerapan model

Project Based Learning (PBL) pada pembelajaran Pendidikan Agama Islam kelas VIII.2 SMP Negeri 2 Suppa Kabupaten Pinrang ?

2. Bagaimana peningkatan minat belajar peserta didik pada pembelajaran Pendidikan Agama Islam kelas VIII.2 SMP Negeri 2 Suppa Kabupaten Pinrang setelah penerapan model Project Based Learning (PBL)?

Adapun tujuan penelitian ini adalah, untuk: 
1. Mengetahui minat belajar peserta didik pada pembelajaran Pendidikan Agama Islam kelas VIII.2 SMP Negeri 2 Suppa Kabupaten Pinrang.

2. Mengetahui peningkatan minat belajar peserta didik pada pembelajaran Pendidikan Agama Islam kelas VIII.2 SMP Negeri 2 Suppa Kabupaten Pinrang melalui penerapan model Project Based Learning (PBL).

Kegunaan penelitian adalah manfaat yang diperoleh dari hasil analisa data yang dikumpulkan berkaitan dengan pengembangan ilmu pengetahuan secara umum. Dalam hal ini meliputi :

1. Hasil penelitian adalah selain menambah pengalaman juga dapat berguna khususnya bagi calon pendidik atau pun calon guru dalam perkembangan peserta didik.

2. Diharapkan hasil penelitian ini dapat digunakan sebagai bahan acuan bagi para guru dan peserta didik terutama dalam proses pembelajaran.

3. Hasil penelitian ini diharapkan dapat digunakan sebagai referensi atau acuan oleh pemerintah selaku penentu kebijakan dalam hal membuat kebijakan yang menyangkut tentang kemajuan pendidik.

4. Hasil penelitian ini diharapkan dapat digunakan sebagai bahan informasi konstuktif dan bahan acuan pendidik dalam Pendidikan Agama Islam agar meningkatkan minat belajar peserta didik.

\section{METODE PENELITIAN}

Desain pada penelitian ini adalah Penelitian Tindakan Kelas (PTK). Menurut Hopkins dalam Masnur Muslich bahwa:

PTK adalah suatu bentuk kajian yang bersifat reflektif, yang dilakukan oleh pelaku tindakan untuk meningkatkan kemantapan rasional dari tindakan-tindakannya dalam melaksanakan tugas dan memperdalam pemahaman terhadap kondisi dalam praktik pembelajaran.

Penelitian Tindakan Kelas juga merupakan suatu pencermatan kegiatan belajar berupa tindakan yang sengaja dimunculkan dan terjadi dalam kelas secara bersama. Tindakan tersebut diberikan oleh pelaku PTK dengan arahan yang harus dilakukan oleh pelajar atau peserta didik.

Mc Niff menegaskan bahwa dasar utama bagi dilaksanakannya penelitian tindakan kelas adalah untuk perbaikan dalam konteks pembelajaran. Tujuan tersebut dapat dicapai dengan melakukan berbagai 
tindakan alternatif dalam memecahkan berbagai persoalan pembelajaran. Oleh karenanya fokus penelitian tindakan kelas terletak pada alternatif tindakan yang direncanakan, kemudian diujicobakan dan selanjutnya dievaluasi apakah alternatif tersebut dapat digunakan untuk memecahkan persoalan pembelajaran yang sedang dihadapi peserta didik atau tidak.

Prosedur yang direncanakan haruslah sistematis dan efisien menurut sasaran ketercapaian tujuan yang telah dirancang sebelumnya. Terkait dengan hal tersebut maka prosedur dalam penelitian ini menggunakan dua siklus, masing-masing siklus tersebut terdiri dari empat langkah yaitu perencanaan, tindakan/pelaksanaan, observasi/pengamatan, dan refleksi.

Memperoleh data yang akurat terkait subjek yang diteliti, maka dalam suatu penelitian diperlukan teknik pengumpulan data yang baik, dalam hal ini dibutuhkan berbagai alat pengumpulan data atau instrument penelitian yang sesuai dengan masalah yang diteliti. Instrument sangat erat hubungannya dengan seluruh unsur penelitian, terutama dengan metode. Secara fungsional instrumen penelitian berfungsi untuk memperoleh data yang diperlukan ketika peneliti telah masuk pada tahap pengumpulan informasi. Langkah yang ditempuh dalam menyusun instrument penelitian berpedoman pada:

1. Pendekatan penelitian yang digunakan

2. Jenis data yang diperlukan untuk menguji hipotesis

3. Instrument yang dianggap cocok untuk mengumpulkan data yang diperlukan.

4. Perlu tidaknya modifikasi berbagai jenis instrument pengumpulan data yang telah ada untuk kepentingan penelitian yang akan dilaksanakan

Berdasarkan jenis penelitian yang digunakan yaitu Penelitian Tindakan Kelas (PTK) maka terdapat beberapa instrument pengumpulan data yang digunakan dalam penelitian ini yaitu:

1. Observasi

Observasi atau pengamatan adalah pengumpulan data yang dilakukan dengan cara mengamati dan mencatat secara sistematik gejalagejala yang diselidiki. Observasi dapat dilakukan dengan dua cara yang kemudian digunakan untuk menyebut jenis observasi yaitu observasi non systematic (yang dilakukan dengan menggunakan instrument pengamatan), dan observasi systematic (yang dilakukan dengan menggunakan pedoman sebagai instrument pengamatan).

2. Dokumentasi 
Dokumentasi (documenter) merupakan suatu teknik pengumpulan data dengan menghimpun dan menganalisis dukomen-dokumen, baik dokumen tertulis, gambar maupun elekrtonik, dokumen ini dipilih sesuai dengan focus masalah. Dokumen yang dilaporkan dalam penelitian adalah dokumen yang telah dianalisis.

\section{HASIL PENELITIAN}

Berdasarkan hasil penelitian mulai dari Pra-siklus ke siklus I dan sampai pada siklus II, minat belajar peserta didik pada pembelajaran Pendidikan Agama Islam melalui penerapan model Project Based Learning (PBL) terus mengalami peningkatan terlihat dari hasil skor peningkatan minat belajar peserta didik pada setiap siklus. Hal ini juga diikuti oleh peningkatan pemahaman peserta didik terhadap materi yang diajarkan selama penelitian berlangsung sehingga pembelajaran dapat dikatakan efektif dan efisien.

Tabel Nilai Perolehan Rata-rata dan Kategori Tiap Siklus

\begin{tabular}{|c|c|c|}
\hline Siklus & $\overline{\mathbf{A}}$ & Kategori \\
\hline Pra siklus & 2,24 & Rendah \\
\hline Siklus I & 3,34 & Tinggi \\
\hline Siklus II & 5,02 & Sangat Tinggi \\
\hline
\end{tabular}

Berdasarkan data tabel 4.4 maka dapat dideskripsikan bahwa ada perubahan atau peningkatan minat belajar peserta didik yang terjadi pada prasiklus, siklus I, dan siklus II. Pada saat pelaksanaan tindakan (pra-siklus), hasil observasi awal menunjukkan rata-rata minat belajar peserta didik adalah 2,24. Selanjutnya setelah dilakukan tindakan pada siklus I dengan model Project Based Learning (PBL), diperoleh rata-rata minat belajar adalah 3,34. Namun peningkatan tersebut belum signifikan, maka penelitian dilanjutkan pada siklus II dengan memperhitungkan hasil refleksi pada siklus I. Pada pelaksanaan tindakan siklus I menunjukkan rata-rata minat belajar peserta didik adalah 3,34 selanjutnya setelah dilakukan tindakan pada siklus II dengan model Project Based Learning (PBL), diperoleh ratarata minat belajar peserta didik 5,52. Peningkatan tersebut telah mencapai taraf signifikan, maka penelitian dicukupkan pada siklus II. 
Sehingga dapat diajukan suatu rekomendasi bahwa penerapan model Project Based Learning (PBL), dapat meningkatkan minat belajar peserta didik pada pembelajaran Pendidikan Agama Islam kelas VIII.2 SMP Negeri 2 Suppa.

\section{PEMBAHASAN}

\section{Kondisi awal sebelum PTK (Pra-Siklus)}

Berdasarkan data yang diperoleh dari pihak sekolah, jumlah keseluruhan peserta didik pada kelas VIII.2 SMP Negeri 2 Suppa Kabupaten Pinrang berjumlah 25 peserta didik, dengan rincian 14 peserta didik laki-laki, dan 11 peserta didik perempuan. Adapun jumlah peserta didik yang diikutsertakan dalam PTK berjumlah 23 peserta didik.

Tahap awal peneliti melakukan pembagian angket minat belajar pada tanggal 13 Desember 2018, untuk mengetahui minat belajar yang dimiliki pada kelas VIII.2 SMP Negeri 2 Suppa, kegiatan ini dilakukan dengan menyuruh peserta didik mengisi angket yang telah dibagikan untuk mengetahui skor perolehan minat belajar awal. Berdasarkan hasil pengamatan awal yang dilakukan peneliti, didapatkan beberapa gambaran tentang minat belajar peserta didik dalam pembelajaran sebagai berikut:

1 Guru Pendidikan Agama Islam memberikan materi pembelajaran menggunakan metode ceramah dan pemberian tugas-tugas.

2 Interaksi antara peserta didik dengan peseta didik lainnya sangat kurang karena pembelajaran hanya berpusat pada kegiatan guru (teacher center) sehingga tidak ada pemicu interaksi antar peserta didik.

Adapun kategori peningkatan minat belajar peserta didik melalui penerapan model Project Based Learning (PBL) dikatakan meningkat apabila dari prasiklus, siklus I, dan siklus selanjutnya mengalami peningkatan skor rata-rata. Berdasarkan pengamatan awal yang dilakukan untuk mengetahui seberpa besar minat belajar peserta didik dalam mempelajarai Pendidikan Agama Islam dengan cara memberikan kepada peserta didik sebuah peryataan melalui pembagian angket, dapat diketahui bahawa hasil rata-rata 2,24, jika rata-rata 2,24 menunjukkan bahwa minat belajar prasiklus dalam kategori rendah antara $(1,5 \leq \bar{A}<2,5)$ dengan demikian, dapat dikatakan bahwa minat belajar peserta didik masih 
tergolong rendah pada pembelajaran Pendidikan Agama Islam. Pelaksanaan peneliti pada siklus I memiliki empat tahap diantaranya adalah:

1. Tahap perencana, berdasarkan pengamatan awal sebelum PTK terhadap peserta didik diperoleh data yang menyebutkan bahwa minat belajar peserta didik berada pada kategori rendah. Oleh karena itu dibutuhkan perencanaan yang tepat sebelum pelaksanaan tindakan dilakukan, adapun rencana yang telah disiapkan sebagai berikut: a) Menyusun Rencana Pelaksanaan Pembelajaran (RPP). b) Menentukan dan menyiapkan perangkatperangkat pembelajaran yang akan digunakan dalam proses pembelajaran. c) Menyiapkan perangkat penelitian berupa lembar observasi minat belajar peserta didik.

2. Tahap Pelaksanaan/Tindakan, Pelaksanaan siklus I dilakukan dalam dua pertemuan dengan materi Pendidikan Agama Islam (Hormat dan Patuh Kepada Orang Tua dan Guru) melalui implementasi model Project Based Learning (PBL), adapun deskripsi tahap pelaksanaan sebagai berikut: a) Kegiatan pembelajaran dilakukan sesuai dengan rencana pelaksanaan pembelajaran dengan menggunakan model Project Based Learning (PBL). b) Menampilkan sebuah tayangan slide dengan materi hormat dan patuh kepada orang tua dan guru, sementara peserta didik antusias menyimak dan menganalisis materi tersebut. c) Setelah menampilkan tayangan slide, melaksanakan tanya jawab terhadap peserta didik terkait materi ajar untuk melihat seberapa jauh penguasaan materi yang diperoleh. d) Setelah itu pendidik membagi peserta didik 5 kelompok secara acak, setiap kelompok dibagikan kertas kerja dan kotak gabus untuk mencatat hal-hal yang penting atau yang menjadi pokok dari materi yang dibawakan, untuk mereka persentasikan didepan kelas nantinya. e) Mengadakan observasi dalam proses pembelajaran yang dilakukan oleh peneliti terhadap pelaksanaan tindakan kelas dalam siklus I menggunakan lembar observasi.

3. Tahap Observasi/Pengamatan, Selama tahap pelaksanaan/ tindakan siklus I berlangsung, peneliti juga melakukan observasi/pengamatan terhadap peningkatan minat belajar peserta didik melaui lembar observasi peserta didik (terlampir) dan dokumentasi yang dibantu oleh observer. 
Belum sesuai dengan rencana, hal tersebut disebabkan oleh sebagian peserta didik belum terbiasa belajar dengan penggunaan model Project Based Learning (PBL), peserta didik juga terkesan malu, kurang percaya diri dan peserta didik belum bisa mengetahui tingkat minat belajar melalui penerapan model Project Based Learning (PBL).

Berdasarkan masalah tersebut, peneliti melakukan upaya dengan memberikan pemahaman-pemahaman kepada peserta didik mengenai kompetensi yang harus dikuasai dengan menggunakan model Project Based Learning (PBL) serta memberikan penjelasan bahwa pentingnya konsentrasi dalam menyimak, baik itu melalui pandangan dan pendengaran sehingga materi yang diterima melalui model Project Based Learning (PBL) mengenai hormat dan patuh pada orang tua dapat dipahami oleh peserta didik.

Hasil dengan rata-rata 3,34, jika rata-rata 3,34 menunjukkan bahwa minat belajar siklus I berada pada kategori tinggi antara $(3,5 \leq \bar{A}<4,5)$ dengan demikian dapat dikatakan bahwa melalui penerapan model Project Based Learning (PBL), pada siklus I peserta didik memperoleh tingkat minat belajar berada pada kategori tinggi pada pembelajaran Pendidikan Agama Islam, rincian skor minat belajar siklus I dapat dilihat pada lembar observasi (terlampir).

Beberapa hal yang perlu direfleksikan kedalam tindakan pada siklus selanjutnya pada pelaksanaan pembelajaran dengan model Project Based Learning (PBL) sebagai berikut:

1. Pemberian materi dengan model yang digunakan dalam hubungannya dengan waktu pembelajaran masih belum efisien.

2. Media, alat, dan perlengkapan pendukung masih perlu dilengkapi.

3. Pada pembelajaran masih perlu dilakukan evaluasi dan uji hasil.

Hasil dengan rata-rata 5,52, jika rata-rata 5,52 bahwa minat belajar siklus II berada pada kategori sangat tinggi antara $(4,5 \leq \overline{\mathrm{A}}<6)$ dengan demikian dapat dikatakan bahwa melalui penerapan model Project Based Learning (PBL), pada siklus II peningkatan minat belajar peserta didik sudah dikatakan sangat tinggi pada pembelajaran Pendidikan Agama Islam, rincian skor minat belajar siklus II dapat dilihat pada lembar observasi. Berdasarkan hasil dari pelaksanaan pembelajaran siklus II menunjukkan bahwa tingkat minat belajar yang diperoleh peserta didik telah mencapai kategori sangat tinggi atau menunjukkan peningkatan yang signifikan, 
sehingga penelitian dicukupkan pada II siklus saja. Selama penelitian siklus II berlangsung, dapat direfleksikan bahwa:

1. Peserta didik telah memperoleh peningkatan pada minat belajar dalam pembelajaran.

2. Peserta didik dapat memahami model Project Based Learning (PBL).

3. Penerapan model Project Based Learning (PBL) dapat meningkatkan minat belajar peserta didik pada pembelajaran Pendidikan Agama Islam telah terlaksana dengan baik.

\section{KESIMPULAN}

Berdasarkan hasil penelitian tindakan kelas yang telah dilaksanakan dua siklus dengan penerapan model Project Based Learning (PBL) dalam pembelajaran Pendidikan Agama Islam dapat dikemukakan kesimpulan bahwa:

1. Sebelum penerapan model Project Based Learning (PBL) pada pembelajaran Pendidikan Agama Islam dapat dikatakan bahwa minat belajar peserta didik berada pada kategori rendah yaitu 2,24. Adapun yang menjadi faktor rendahnya minat belajar peserta didik dalam pelajaran Pendidikan Agama Islam yaitu adanya kesulitan dalam memahami materi tersebut secara menyeluruh, karena materi sangat padat dan banyak. Dengan demikian, dibutuhkan penerapan model yang efektif agar dapat dipahami secara mudah oleh peserta didik.

2. Setelah penerapan model Project Based Learning (PBL), minat belajar peserta didik pada pembelajaran Pendidikan Agama Islam di kelas VIII.2 SMP Negeri 2 Suppa telah mengalami peningkatan dengan rata-rata skor perolehan 5,52. Peningkatan ini berawal dari pra-siklus yaitu sebesar 2,24 kemudian diterapkan model Project Based Learning (PBL) melalui siklus I, meningkat menjadi 3,37 dan dilanjutkan pada siklus II, dengan peningkatan yang signifikan yaitu 5,52 .

Adapun hambatan-hambatan yang dirasakan yaitu, peserta didik susah untuk diatur, kurangnya media, alat, dan perlengkapan pendukung, waktu pembelajaran masih belum efesien.

Kelemahan pada model Project Based Learning (PBL) yaitu; membutuhkan banyak waktu dalam menyelesaikan permasalahan, membutuhkan banyak dana, banyaknya peralatan yang mesti dipersiapkan, 
peserta didik yang memiliki kelemahan dalam hal percobaan dan pengumpulan informasi akan mengalami kesulitan karena minimnya sumber belajar, akan adanya kemungkinan peserta didik yang tidak terlibat dalam kegiatan dikarenakan peserta didik masih terkesan malu dan kurang percaya diri, pelaksanaan proyek menjadi langkah yang paling banyak mengalami kendala dikarenakan banyak hal yang tidak sesuai dengan rencana yang telah dibuat, seperti kehadiran peserta didik, ketepatan waktu, pembagian tugas dan penggunaan bahasa, terakhir yaitu lokasi waktu pembelajaran Pendidikan Agama Islam yang terbatas dan terpotong-potong.

\section{DAFTAR PUSTAKA}

Arikunto, Suharsimi. 1998. Prosedur Penelitian: Suatu Pendekatan Praktek. Jakarta;RinekaCipta.

Ali, Mohammad. 1993. Strategi Penelitian Pendidikan. Bandung: Angkasa.

Achmadi, Abu dan Choliddan Narbuko. 2009. Metodologi Penelitian. Jakarta:Bumi Aksara.

Dinata, Sukma. at al.eds. 2008. Metode Penelitian Pendidikan. Bandung: PT Remaja Rosda karya.

Isnawati, Nurlaela. 2010. Guru Positif-

Motivatif. Cet. I; Jogjakarta: Laksana.

Muslich, Masnur. 2014. Melaksanakan PTK Penelitian Tindakan Kelas Itu Mudah. Jakarta:Bumi Aksara.

Slameto. 2003. Belajar dan Faktor-Faktor yang Mempengaruhinya. Cet. IV; Jakarta: PT Rineka Cipta.

Rusman. 2016. Model-Model Pembelajaran Mengembangkan Profesionalisme Guru. Cet.VI; Jakarta: PT Raja Grafindo Persada. 